\title{
PDIA6 contributes to aerobic glycolysis and cancer progression in oral squamous cell carcinoma
}

\author{
Ling $\mathrm{MaO}^{1,2+}{ }^{2}$ Xiaoweng $\mathrm{Wu}^{3+}$, Zhengpeng Gong ${ }^{4}$, Ming $\mathrm{Yu}^{5,6^{*}}$ and Zhi Huang ${ }^{6,7^{*}}$ (D)
}

\begin{abstract}
Background/objective: Accumulated evidence has demonstrated that aerobic glycolysis serves as a regulator of tumor cell growth, invasion, and angiogenesis. Herein, we explored the role of protein disulfide isomerase family 6 (PDIA6) in the aerobic glycolysis and the progression of oral squamous cell carcinoma (OSCC).

Methods: The expression pattern of PDIA6 in OSCC tissues was determined by qPCR and western blotting. Lentivirus and small interfering RNAs (siRNAs) were introduced into cells to upregulate and downregulate PDIA6 expression. CCK-8, flow cytometry, transwell, and xenotransplantation models were applied to detect cell proliferation, apoptosis, migration, invasion, and tumorigenesis, respectively.
\end{abstract}

Results: A high expression pattern of PDIA6 was observed in OSCC tissues, which was closely associated with lower overall survival and malignant clinical features in OSCC. Compared with the control group, overexpression of PDIA6 induced significant enhancements in cell growth, migration, invasiveness, and tumorigenesis and decreased cell apoptosis, while knockdown of PDIA6 caused opposite results. In addition, overexpression of PDIA6 increased glucose consumption, lactate production, and ATP level in OSCC cells.

Conclusion: This study demonstrated that PDIA6 expression was elevated in OSCC tissues, and overexpression of it promoted aerobic glycolysis and OSCC progression.

Keywords: PDIA6, Proliferation, Migration, Aerobic glycolysis, Tumorigenesis

\section{Introduction}

Oral squamous cell carcinoma (OSCC), as a major type of head and neck cancer, ranks the sixth most common malignant tumor in the world and ranks eighth in cancer-related mortalities [1]. It is reported that about 354,800 new cases are diagnosed with OSCC and 177, 400 people died of OSCC annually [2]. Despite big

\footnotetext{
* Correspondence: $376774091 @ q q . c o m ;$ doctor@huangzhi.com

${ }^{\dagger}$ Ling Mao and Xiaoweng Wu contributed equally to this study and served as co-first authors.

${ }^{5}$ Laryngology and Otology, the Affiliated Baiyun Hospital of Guizhou Medical University, No. 108 Gangyu Road, Guiyang 550005, People's Republic of China

${ }^{6}$ Department of Interventional Radiology, the Affiliated Cancer Hospital of Guizhou Medical University, Guiyang 550002, People's Republic of China Full list of author information is available at the end of the article
}

progresses being achieved in treatment and diagnosis, the 5-year survival rate for OSCC is only about $50 \%$ and the regional recurrence rate is $33 \sim 40 \%[3,4]$. High invasiveness and metastasis rates are two main reasons for the worse outcome of OSCC [5]. Thus, it is urgent to uncover the molecular mechanisms underlying OSCC development.

Aerobic glycolysis, also known as the Warburg effect, is one of the main features of cancer cells [6, 7]. Generally, glucose uptake and lactate production are increased in tumor cells via the aerobic glycolysis pathway to meet the requirement of elevated bioenergetic and biosynthetic demand for growth, metastasis, and invasion, leading to lactate content increase and $\mathrm{pH}$ value decrease

(c) The Author(s). 2021 Open Access This article is licensed under a Creative Commons Attribution 4.0 International License, which permits use, sharing, adaptation, distribution and reproduction in any medium or format, as long as you give appropriate credit to the original author(s) and the source, provide a link to the Creative Commons licence, and indicate if changes were made. The images or other third party material in this article are included in the article's Creative Commons licence, unless indicated otherwise in a credit line to the material. If material is not included in the article's Creative Commons licence and your intended use is not permitted by statutory regulation or exceeds the permitted use, you will need to obtain permission directly from the copyright holder. To view a copy of this licence, visit http://creativecommons.org/licenses/by/4.0/ The Creative Commons Public Domain Dedication waiver (http://creativecommons.org/publicdomain/zero/1.0/) applies to the data made available in this article, unless otherwise stated in a credit line to the data. 
[8]. Evidence has demonstrated that elevated lactate level is closely associated with tumor growth, invasion, and angiogenesis $[9,10]$. For example, Cai et al. [11] reported that lactate dehydrogenase A (LDHA) was highly expressed in OSCC tissues and cell lines, and knockdown of it repressed cell proliferation, migration, invasion, and in vivo tumor formation through inhibiting glycolysis. Targeting aerobic glycolysis pathway is a promising method for cancer treatment [12].

Protein disulfide isomerase family 6 (PDIA6), also known as ERP5 or P5, belongs to the protein disulfide isomerase (PDI) family that assists protein folding and inhibits the polymerization of unfolded substrates and oxidoreductases to facilitate the formation of disulfide bonds $[13,14]$. Recently, researches have demonstrated that PDIA6 is overexpressed in several kinds of human cancers and serves as an oncogene, such as lung cancer [15], bladder cancer [16], and hepatocellular carcinoma [17]. However, whether PDIA6 is involved in the aerobic glycolysis and the progression of OSCC still needs to be elucidated.

In the present study, we aimed to explore the expression pattern of PDIA6 in OSCC tissues and to reveal its role in the aerobic glycolysis and the progression of OSCC.

\section{Materials and methods}

\section{Ethics statement}

The current study has got the approval of the ethics committee of Guizhou Medical University (No. 2001221).

\section{Clinical tissue samples}

Fifty-eight OSCC tissues and the adjacent noncancerous tissues were obtained from patients with primary OSCC undergoing surgical resection. No patients received chemotherapy or radiotherapy prior to surgery. All specimens were confirmed by two pathologists. The written informed consents were signed by every patient, and the current study has got the approval of the ethics committee of Guizhou Medical University. All tissue samples were rapidly placed at $-80^{\circ} \mathrm{C}$ for further study. The OSCC patients were divided into PDIA6 high expression and low expression groups based on the mRNA levels of PDIA6. In detail, the $2^{-\Delta \Delta \mathrm{Ct}}$ method was used to calculate the relative expression level of PDIA6 mRNA to the adjacent noncancerous tissues in every cancer tissue sample. Then, the OSCC patients were divided into the high expression group and low expression group according to the relative expression median. If the expression level of PDIA6 was $\geq$ the median (which was 1.9 in the current study), PDIA6 was considered as high expression. If the expression level of PDIA6 was < the median, PDIA6 was considered as low expression.

\section{Cell lines and culture method}

Two human OSCC cell lines, SCC9 and Cal27, were all purchased from ATCC (Manassas, VA, USA). SCC9 cells were seeded in Eagle's medium and Ham's F12 medium, and Cal27 cells were placed in DMEM, with $10 \%$ fetal bovine serum (FBS) and $1 \%(\mathrm{v} / \mathrm{v})$ penicillin/streptomycin. All cells were kept in a humidified atmosphere with $5 \% \mathrm{CO}_{2}$ with a stationary temperature of $37^{\circ} \mathrm{C}$. Cell culture medium and FBS were purchased from Invitrogen (Carlsbad, CA, USA).

\section{Lentivirus and small interfering RNAs (siRNAs)}

The lentivirus vectors applied to overexpress PDIA6 (called OE-PDIA6), and the siRNA used to downregulate PDIA6 (called si-PDIA6) and their negative controls (OE-NC, si-NC) were all purchased from Shanghai GenePharma Co., LTD (Shanghai, China). The lentivirus vectors were introduced into cells via cell infection by using polybrene, and si-PDIA6 and si-NC were introduced into cells via cell transfection using Lipofectamine 2000 reagent (Invitrogen). The infected cells were incubated in G418 $(100 \mu \mathrm{g} / \mathrm{ml})$ for 14 days to establish the stable cell lines which were used in the in vivo assay.

\section{Real-time quantitative polymerase chain reaction (qPCR)}

Total RNA was extracted from tissues and cells by using TRIzol reagent (Life Technologies, Waltham, MA, USA) referring to the manufacturer's manual. Then, the cDNA was produced using a PrimeScriptTM 1st Strand cDNA Synthesis Kit (Takara, Dalian, China). After that, the cDNA was served as substrate for qPCR with SYBR Premix Ex Taq (Takara) on an ABI 7900 system (Applied Biosystems, Foster City, CA, USA). The $2^{-\Delta \Delta C t}$ method was applied to analyze the relative levels of mRNAs after being normalized to that of the expression level of $\beta$ ACTIN. The sequences used in this experiment are listed in Table 1.

\section{Western blotting assay}

Total protein was obtained from cells using the RIPA lysis buffer (Beyotime, Jiangsu, China), supplemented with $1 \%(\mathrm{v} / \mathrm{v})$ protease inhibitors (Beyotime). Then, $30 \mu \mathrm{g}$ protein sample obtained from every group was separated by $10 \%$ sodium dodecyl sulfate-polyacrylamide gel electrophoresis, followed by transformation into the polyvinylidene difluoride membranes (Millipore, Billerica, MA, USA). The membranes were then successively incubated with $5 \%$ fat-free milk for $1 \mathrm{~h}$ at room temperature and probed with the primary antibodies, including PDIA6 (1:2,000 dilution; No. ab11432, Abcam, Cambridge, MA, USA) and $\beta$-actin (No. ab8226, Abcam,

Table 1 Primer sequences

\begin{tabular}{|c|c|c|}
\hline Gene & Sense $\left(5^{\prime}-3^{\prime}\right)$ & Antisense $\left(5^{\prime}-3^{\prime}\right)$ \\
\hline PDIA6 & CACTAGGCGCTCACTGTTC & GAGGGATCTCGCTCCTGGAA \\
\hline$\beta$-actin & TGCGTGACATTAAGGAGA AG & GCTCGTAGCTCTTCTCCA \\
\hline
\end{tabular}


1:5,000 dilution) overnight at $4{ }^{\circ} \mathrm{C}$. After that, the membranes were probed with secondary antibodies (Abcam) for $1 \mathrm{~h}$. Protein signals were detected using iBright CL750 (Thermo Fisher Scientific, MA, USA) after incubation with ECL (Thermo Fisher Scientific).

\section{CCK-8 assay}

The proliferation assay was performed with the Cell Counting Kit-8 (CCK-8) assay. First, the OSCC cells (2500 cells for each well) were seeded in 96-well plates, allowed to adhere, transfected, and then cultured at $37^{\circ} \mathrm{C}$ for $0,24,48$, and $72 \mathrm{~h}$. Then, $10 \mu \mathrm{l} \mathrm{CCK-8} \mathrm{solution}$ (Abcam) was added to each well and allowed to incubate for further $4 \mathrm{~h}$ at $37^{\circ} \mathrm{C}$. The OD values at $450 \mathrm{~nm}$ were determined using a spectrophotometer (BioTek Instruments, Winooski, VT, USA).

\section{Flow cytometry assay}

Cell apoptotic rates were determined by using the flow cytometry assay. The cells were resuspended in $500 \mu \mathrm{l}$ $1 \mathrm{X}$ binding buffer and incubated with $5 \mu \mathrm{l}$ Annexin VFITC in the dark for $15 \mathrm{~min}$, followed by incubation with propidium iodide (PI) in the dark for $5 \mathrm{~min}$. The cells were then tested for apoptosis on flow cytometry (BD Biosciences, Franklin Lakes, NJ, USA). The results were analyzed using Flowjo 7.6 software.

\section{Transwell chamber assay}

Cell migration and invasiveness were assessed with Transwell chambers $(8 \mu \mathrm{m}$, Corning, NY, USA $)$ in 24well plates using uncoated or Matrigel (BD Biosciences, San Jose, USA)-coated membranes. In brief, OSCC cells in the culture medium with $1 \%$ FBS were seeded in the upper well with $1 \times 10^{5}$ cells for each well, and $600 \mu \mathrm{l}$ cell culture medium with $10 \%$ FBS was added in the lower chambers. After $24 \mathrm{~h}$ or $48 \mathrm{~h}$ of incubation, the cells that did not penetrate the membrane on the upper chamber were removed with a cotton swab. Cells in the lower membrane were fixed with methanol and stained with $0.1 \%$ crystal violet solution. After washing with PBS for 4-5 times, the numbers of stained cells in 6 random fields were counted under an inverted microscope.

\section{Detection of lactate production, glucose consumption, and ATP levels}

OSCC cells were inoculated in 6-well plates at a density of $2 \times 10^{5}$ cells and allowed to attach. Following $24 \mathrm{~h}$ of incubation, the medium was collected to measure lactate production and glucose consumption with commercial kits from Nanjing Jiancheng Biotech (Jiangsu, China; A019) and Applygen Co., LTD (Beijing, China; No. E1010) according to the manufacturer's descriptions, respectively. ATP levels were tested using an ATP Colorimetric/Fluorometric Assay Kit (Sigma-Aldrich, MO, USA) according to the manufacturer's instructions.

\section{Tumor xenograft}

Male NOD/SCID mice aged 5-6 weeks obtained from Wuhan Huaguenke Biotechnology Co. LTD (Hubei, China) were randomly divided into $\mathrm{OE}-\mathrm{NC}$ and $\mathrm{OE}-$ PDIA6 groups ( $n=5$ for each group). This animal assay has got the approval of the Experiment Ethics Committee of Guizhou Medical University. Approximately $5 \times$ $10^{6}$ SCC9 cells with OE-NC or OE-PDIA6 stable transfection were suspended in $200 \mu \mathrm{l}$ of PBS and then subcutaneously injected into the armpit of mice. The tumors were measured to assess tumor formation every week: tumor volume $=$ length $\times$ width $^{2} / 2$. The mice were euthanized 4 weeks after injection, and the tumor xenografts were harvested and weighed.

\section{Statistical analysis}

Data are expressed as mean \pm standard deviation (SD) from 3 independent experiments. SPSS software (version 23.0, SPSS Inc., Chicago, IL, USA) was applied for statistical analyses. Two-sidet tests and one-way ANOVA with Bonferroni post hoc tests were used to compare differences, such as expression levels, apoptotic rates, absorbance values, migration cell numbers, invasion cell numbers, glucose consumption, lactate production and ATP levels, tumor weights, and tumor volumes, between two and $\geq 3$ groups. Kaplan-Meier survival curves with log-rank tests were used to evaluate the relationship between PDIA6 expression levels and OSCC patients' overall survival. The value of $p<0.05$ was considered statistically significant.

\section{Results}

PDIA6 was overexpressed in OSCC tissues

To explore the role of PDIA6 in the progression of OSCC, we first assessed its expression profile in OSCC tissues. Compared with the adjacent noncancerous tissues, the expression of PDIA6 was significantly elevated in cancer tissues at both mRNA and protein levels, as detected by qPCR (Fig. 1a) and western blotting (Fig. 1b). This result suggested that the high expression of PDIA6 might play a role in the progression of OSCC.

\section{PDIA6 high expression predicted poor prognosis and malignant clinicopathologic features in OSCC}

Then, we evaluated the clinical value of PDIA6 in OSCC. The overall survival for patients of the PDIA6 high expression group was significantly lower than that of the PDIA6 low expression group (Fig. 1c). In addition, the 


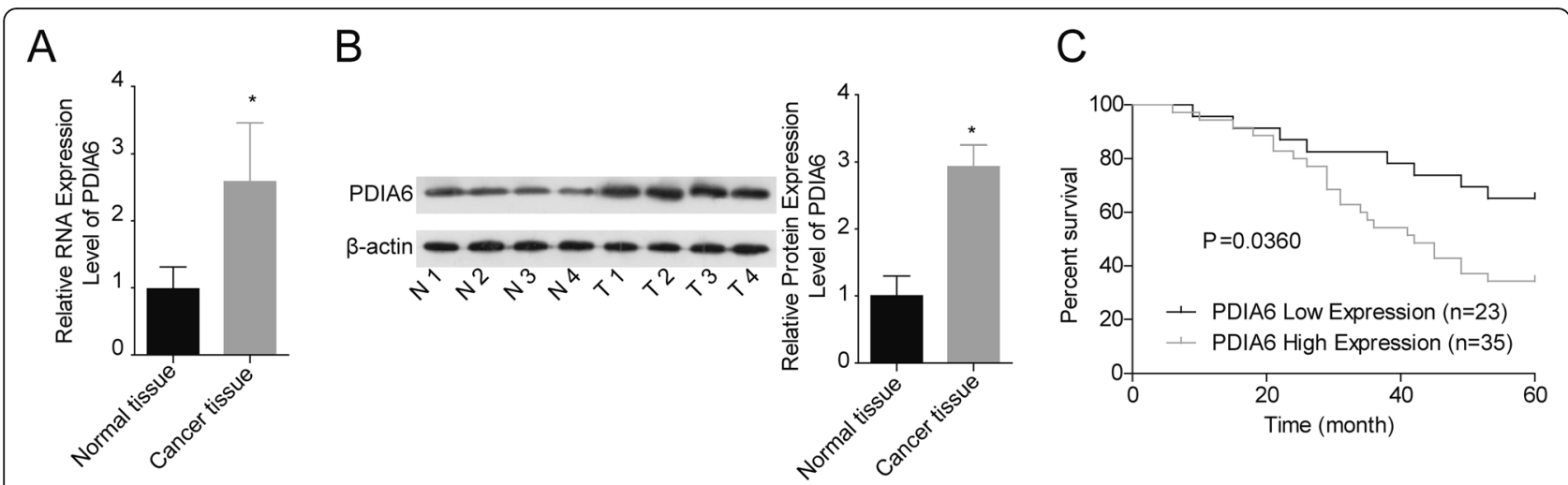

Fig. 1 PDIA6 was highly expressed in OSCC tissues and predicted with poor prognosis. a The expression levels of PDIA6 mRNA were detected in 58 matched OSCC tissues and the adjacent normal tissues were determined by qPCR. $\mathbf{b}$ The protein levels of PDIA6 in 4 paired OSCC tissues and the adjacent normal tissues were determined by western blotting assay. $\mathbf{c}$ Kaplan-Meier analysis of the relationship between PDIA6 mRNA levels and the overall survival of OSCC patients $\left({ }^{*} p<0.05\right)$

high expression level of PDIA6 was closely associated with higher TNM stage $(p=0.006)$, poorer tissue differentiation $(p=0.036)$, and perineural invasion $(p=0.034)$ in OSCC patients, as shown in Table 2. This result demonstrated that the high expression level of PDIA6 predicted poor prognosis and malignant clinicopathologic features in OSCC.

Table 2 Association of PDIA6 expression with clinicopathological features of OSCC patients

\begin{tabular}{|c|c|c|c|c|}
\hline \multirow[t]{2}{*}{ Characteristics } & \multirow{2}{*}{$\begin{array}{l}\text { Total } \\
\text { number } \\
(n=58)\end{array}$} & \multicolumn{2}{|c|}{ PDIA6 expression } & \multirow{2}{*}{$\begin{array}{l}p \\
\text { value }\end{array}$} \\
\hline & & Low $(n=23)$ & High $(n=35)$ & \\
\hline \multicolumn{2}{|l|}{ Age (years) } & & & 0.074 \\
\hline$\leq 60$ & 32 & 16 & 16 & \\
\hline$>60$ & 26 & 7 & 19 & \\
\hline \multicolumn{2}{|l|}{ Gender } & & & 0.63 \\
\hline Male & 28 & 12 & 16 & \\
\hline Female & 30 & 11 & 19 & \\
\hline \multicolumn{2}{|l|}{ Tumor size (cm) } & & & 0.217 \\
\hline$<3$ & 27 & 13 & 14 & \\
\hline$\geq 3$ & 31 & 10 & 21 & \\
\hline \multicolumn{2}{|l|}{ TNM stage } & & & 0.006 \\
\hline$|-| \mid$ & 25 & 15 & 10 & \\
\hline III-IV & 33 & 8 & 25 & \\
\hline \multicolumn{2}{|c|}{ Tumor differentiation } & & & 0.036 \\
\hline Well & 28 & 15 & 13 & \\
\hline Moderate-poor & 30 & 8 & 22 & \\
\hline \multicolumn{2}{|l|}{ Perineural invasion } & & & 0.034 \\
\hline No & 33 & 17 & 16 & \\
\hline Yes & 25 & 6 & 19 & \\
\hline
\end{tabular}

PDIA6 promoted cell growth and inhibited cell apoptosis in OSCC

Next, gain- and loss-of-function experiments were carried out to assess PDIA6 role in cell proliferation and apoptosis in OSCC cells. PDIA6 expression was significantly increased following cell infection with OE-PDIA6 in SCC9 and Cal27 cells, while PDIA6 level was decreased when cells were transfected with si-PDIA6 at mRNA and protein levels (Fig. 2a, b). Cell proliferation was significantly enhanced while apoptosis was inhibited when PDIA6 was overexpressed in SCC9 and Cal27 cells, while knockdown of PDIA6 induced an obvious repression in cell proliferation and a significant increase in cell apoptosis rate (Fig. 2c-f). These results demonstrated that PDIA6 promoted OSCC cell growth and inhibited cell apoptosis.

\section{PDIA6 facilitated OSCC cell migration and invasion}

In addition, we assessed PDIA6 role in cell migration and invasion in OSCC. Compared with the OE-NC group, cell migration (Fig. 3a) and invasion (Fig. 3b) were all apparently enhanced following PDIA6 overexpression in SCC9 and Cal27 cells, while knockdown of PDIA6 caused opposite results (Fig. 3a, b). These results indicated that PDIA6 served as an inducer in cell migration and invasion in OSCC.

\section{PDIA6 promoted aerobic glycolysis in OSCC}

Moreover, we evaluated the effect of PDIA6 in the aerobic glycolysis in OSCC cells. Compared with the OE-NC group, the glucose consumption (Fig. 4a), lactate production (Fig. 4b), and ATP level (Fig. 4c) all were significantly increased in the OE-PDIA6 group and were decreased in the si-PDIA6 group. These findings suggested that PDIA6 promoted aerobic glycolysis in OSCC. 


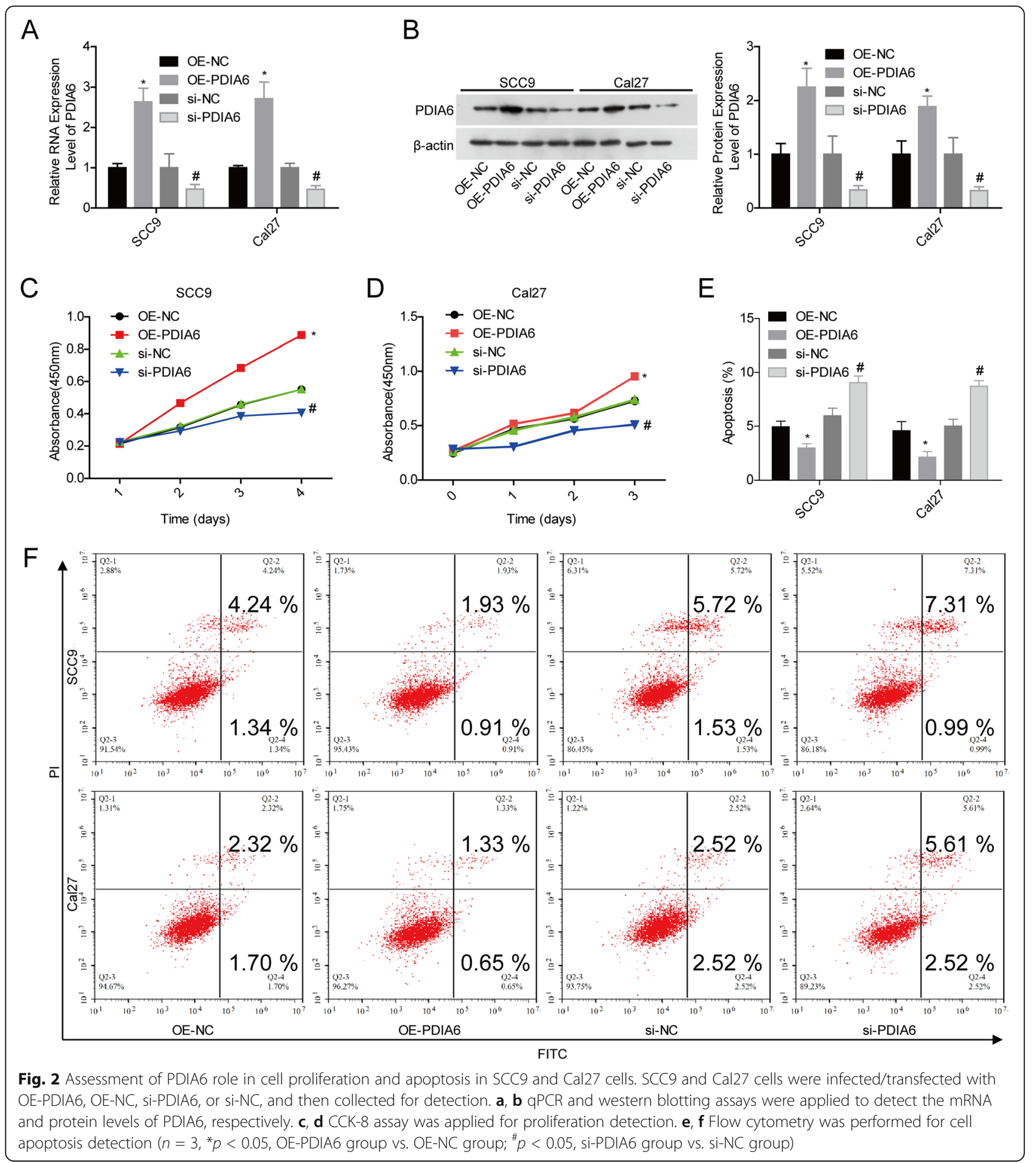

PDIA6 promoted the tumorigenesis of OSCC cells

Finally, we studied PDIA6 role in the in vivo tumor formation ability of SCC9 cells. The result showed that, in comparison with the OE-NC group, the tumor weight and volume were increased when PDIA6 was upregulated in SCC9 cells (Fig. 5a, b), suggesting that PDIA6 enhanced cell tumorigenesis in OSCC.

\section{Discussion}

In the present study, we revealed for the first time that PDIA6 was overexpressed in OSCC tissues and served as 


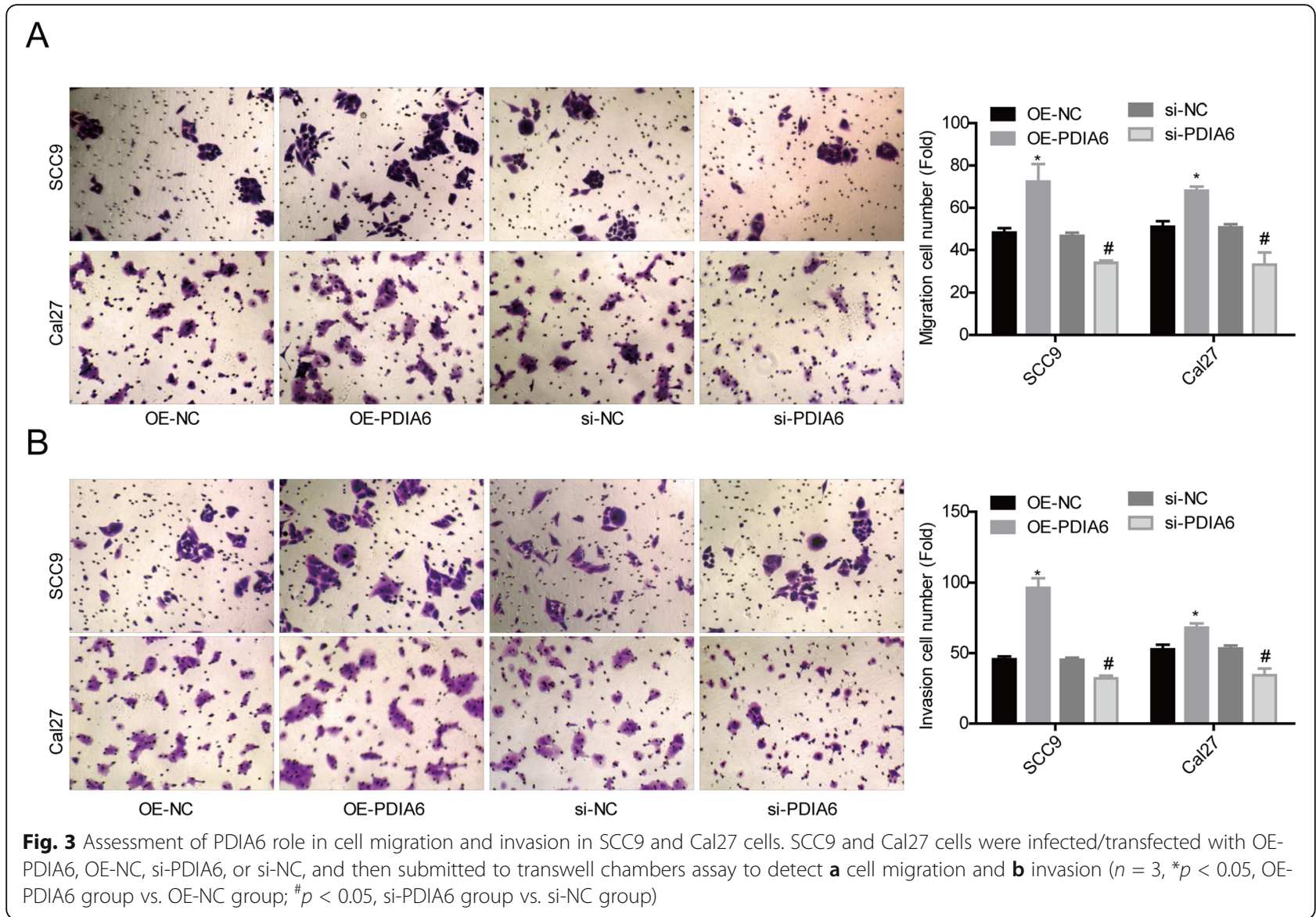

an oncogene to promote OSCC growth, migration, invasion, and in vivo tumor formation and inhibit cell apoptosis through enhancing aerobic glycolysis in OSCC. Focusing on aerobic glycolysis, this study provides a potential therapeutic target for OSCC treatment.

Recently, evidence has demonstrated that PDI family members are frequently overexpressed in some cancers with poor prognosis, high incidence of invasion, and chemoresistance [18]. For instance, Ramos et al. [19] suggested that the expression levels of PDIA3 and PDIA6 were increased in primary ductal breast cancer. Bai et al. [15] found that PDIA6 expression was increased in non-small cell lung cancer (NSCLC) tissues, which correlated with poor prognosis; further experiments showed that silencing of PDIA6 inhibited cell growth and promoted cell apoptosis induced by cisplatin, while augment of PDIA6 caused the opposite results. In OSCC, Yuan et al. [20] used the bioinformatics

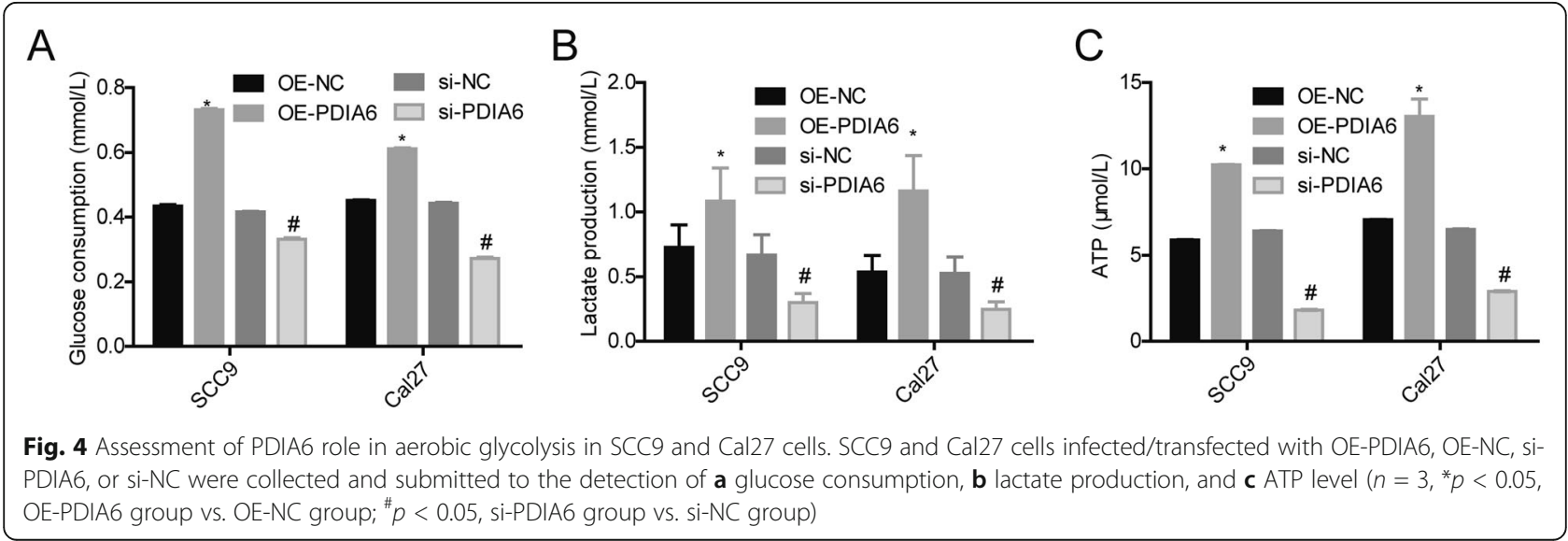




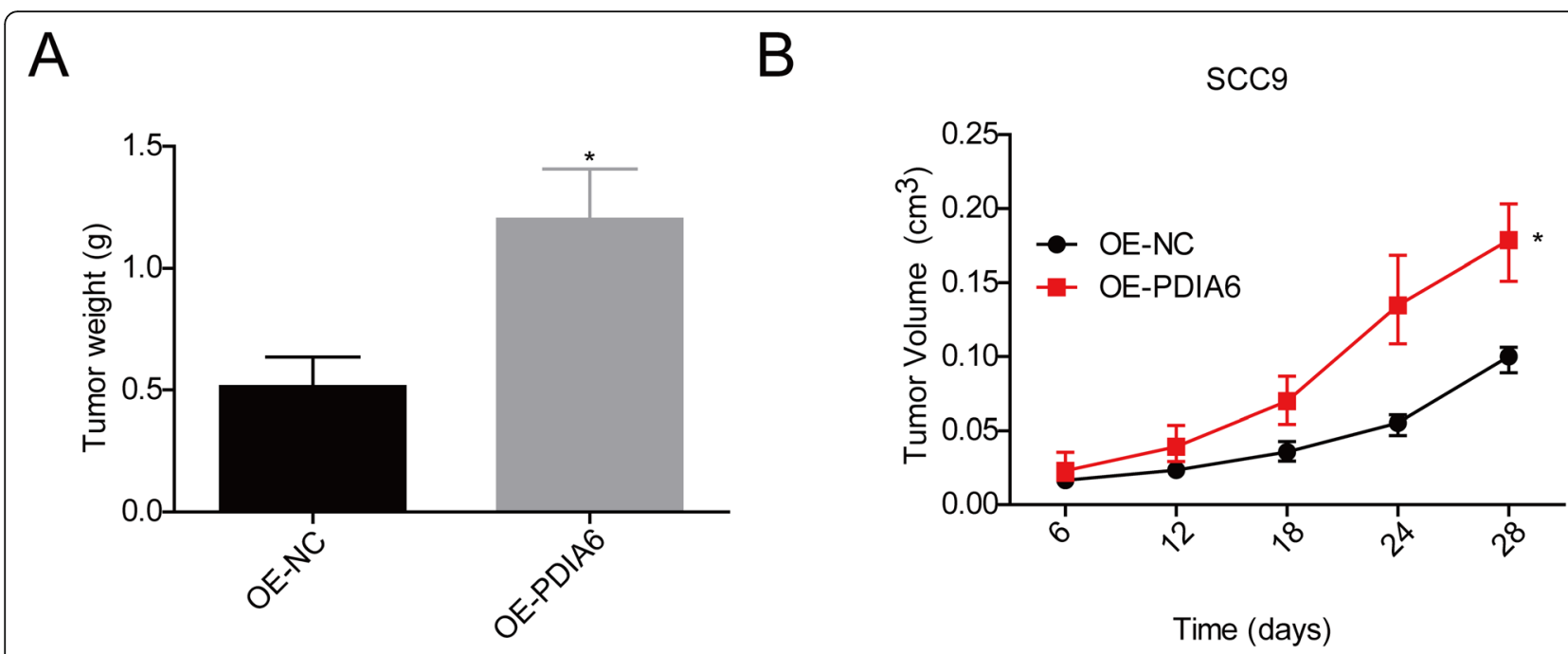

Fig. 5 Overexpression of PDIA6 promoted in vivo tumor formation of SCC9 cells. a Tumor weights and $\mathbf{b}$ volume were assessed in mice injected with OE-NC or OE-PDIA6 stably transfected SCC9 cells $\left({ }^{*} p<0.05\right.$, OE-PDIA6 group vs. OE-NC group)

method and immuno-histochemical assays and observed that PDIA3 level was increased in OSCC tissues, which was further verified by the immuno-histochemical assays. Herein, we evaluated the expression profile of PDIA6 in OSCC tissues using qPCR and western blotting assays and found that PDIA6 expression level was increased in OSCC tissues. PDIA6 expression pattern in OSCC was consistent with NSCLC [15], bladder cancer [16], ovarian cancer [21], and hepatocellular carcinoma [17]. Further analysis showed that a higher level of PDIA6 in OSCC patients was closely associated with lower overall survival, higher TNM stage $(p=0.006)$, poorer tissue differentiation $(p=0.036)$, and perineural invasion $(p=0.034)$. Similarly, the PDIA6 expression level was associated with the presence of lymph node metastasis and hormone receptor status in breast cancer [19].

Through the gain- and loss-of-function assays, we found that PDIA6 overexpression significantly promoted the proliferation, invasion, migration, and tumorigenesis of OSCC cells and resulted in a marked decrease in cell apoptosis rate, illustrating that PDIA6 exerted an oncogenic role in OSCC progression. Up to now, PDIA6 has been verified to serve as an oncogene in several kinds of cancers. Inactivation of PDIA6 directly promoted cisplatin-induced cell death in NSCLC [22]. Overexpression of PDIA6 caused an enhancement in cell proliferation accompanied with accelerated cell cycle progression in HeLa cells via activating wnt $/ \beta$-catenin signaling [23]. Silencing of the PDIA6 gene significantly inhibited bladder cancer cell proliferation, invasion, and in vivo tumor formation and metastasis [16]. Silencing of PDIA6 significantly decreased the tumor volumes to $42.7 \%$ in giant cell tumor stromal cells [24]. However, glioblastoma
U87MG cell migration and invasion were enhanced significantly after inhibition of PDIA6 [25], suggesting that PDIA6 might play an inhibitory role in cell migration and invasion in glioblastoma. The different cell contents might cause this difference.

It has been recognized that cancer cells present with high glycolytic metabolism even in the presence of oxygen $[26,27]$. Glycolysis is beneficial to cancer cells to meet their requirements to maintain rapid growth and migration via providing ATP and metabolic intermediates [28]. Just like other solid cancer cells, OSCC cells get energy to maintain the rapid growth via aerobic glycolysis, resulting in more aggressive behaviors $[29,30]$. Wei et al. [31] revealed that the glucose metabolism was significantly increased in premalignant dysplasic oral tissues when compared to the normal oral mucosa tissues, indicating that glycolysis is implicated in the pathogenesis of oral carcinogenesis. In the present study, we explored whether PDIA6 was involved in aerobic glycolysis. The results showed that overexpression of PDIA6 increased glucose consumption, lactate production, and ATP level in OSCC cells. These results suggested that PDIA6 contributed to aerobic glycolysis in OSCC, leading to OSCC progression.

\section{Conclusion}

In summary, the current findings reveal that PDIA6 expression is elevated in OSCC, and predicted poor outcome and advanced clinical process for OSCC patients. Additionally, PDIA6 functions as an oncogene to promote OSCC growth, migration, invasion, and in vivo tumor formation and inhibit cell apoptosis through enhancing aerobic glycolysis. 


\section{Abbreviations}

OSCC: Oral squamous cell carcinoma; NSCLC: Non-small cell lung cancer; PDIA6: Protein disulfide isomerase family 6; LDHA: Lactate dehydrogenase A; siRNAs: Small interfering RNAs; qPCR: Real-time quantitative polymerase chain reaction

\section{Acknowledgements}

Not applicable.

\section{Authors' contributions}

LM and XW carried out most of the experiments and drafted the manuscript. ZG did parts of the experiments and performed the statistical analysis; MY and $\mathrm{ZH}$ conceived of the study and revised the manuscript. All authors read and approved the final manuscript.

\section{Funding}

This study was supported by the Guiyang Science and Technology Project (No. ZuKeHeTong[2019]-9-14-5), the Guiyang Baiyun District Science and Technology Project (No. [2019]38\#) and Regional common diseases and adult stem cell transformation research innovation platform, Science and Technology Department of Guizhou Province [Guizhou specific grant (2019)4008]

\section{Availability of data and materials}

All data generated or analyzed during this study are included in this published article.

\section{Declarations}

\section{Ethics approval and consent to participate}

The written informed consents were signed by every patient. The current study involving human samples and animal experiment has got the approval of the ethics committee of Guizhou Medical University (No. 2001221).

\section{Consent for publication}

Not applicable.

\section{Competing interests}

The authors declare that they have no competing interests.

\section{Author details}

'The Laboratory of Head and Neck Cancer Research, Hospital and School of Stomatology, Guizhou Medical University, Guiyang 550004, People's Republic of China. ${ }^{2}$ Imaging department, Liaocheng People's Hospital, Liaocheng, China. ${ }^{3}$ Department of Imaging, Liaocheng People's Hospital, 252000 Guiyang, People's Republic of China. ${ }^{4}$ Department of Otorhinolaryngology, The Affiliated Hospital of Guizhou Medical University, Guiyang, China. ${ }^{5}$ Laryngology and Otology, the Affiliated Baiyun Hospital of Guizhou Medical University, No. 108 Gangyu Road, Guiyang 550005, People's Republic of China. ${ }^{6}$ Department of Interventional Radiology, the Affiliated Cancer Hospital of Guizhou Medical University, Guiyang 550002, People's Republic of China. ${ }^{7}$ College of Basic Medicine, Guizhou Medical University, No. 1 Beijingxi Road, Guiyang 550002, People's Republic of China.

Received: 21 October 2020 Accepted: 9 March 2021 Published online: 24 March 2021

\section{References}

1. Warnakulasuriya S. Global epidemiology of oral and oropharyngeal cancer. Oral oncology. 2009;45(4-5):309-16. Epub 2008/09/23. https://doi.org/10.101 6/j.oraloncology.2008.06.002.

2. Bray F, Ferlay J, Soerjomataram I, Siegel RL, Torre LA, Jemal A. Global cancer statistics 2018: GLOBOCAN estimates of incidence and mortality worldwide for 36 cancers in 185 countries. CA Cancer J Clin. 2018;68(6):394-424. Epub 2018/09/13. https://doi.org/10.3322/caac.21492.

3. Vigneswaran N, Williams MD. Epidemiologic trends in head and neck cancer and aids in diagnosis. Oral Maxillofac Surg Clin North Am. 2014;26(2):12341. Epub 2014/05/06. https://doi.org/10.1016/j.coms.2014.01.001.

4. Bello IO, Soini Y, Salo T. Prognostic evaluation of oral tongue cancer: means, markers and perspectives (II). Oral Oncol. 2010;46(9):636-43. Epub 2010/07/ 20. https://doi.org/10.1016/j.oraloncology.2010.06.008.
5. Jerjes W, Upile T, Petrie A, Riskalla A, Hamdoon Z, Vourvachis M, Karavidas K, Jay A, Sandison A, Thomas GJ, Kalavrezos N, Hopper C. Clinicopathological parameters, recurrence, locoregional and distant metastasis in 115 T1-T2 oral squamous cell carcinoma patients. Head Neck Oncol. 2010;2(1):9. Epub 2010/04/22. https://doi.org/10.1186/1758-3284-2-9.

6. Chen G, Zhang Y, Liang J, Li W, Zhu Y, Zhang M, et al. Deregulation of hexokinase II is associated with glycolysis, autophagy, and the epithelialmesenchymal transition in tongue squamous cell carcinoma under hypoxia. BioMed Res Int. 2018;2018:8480762 Epub 2018/04/24.

7. Chen G, Liu H, Zhang Y, Liang J, Zhu Y, Zhang M, Yu D, Wang C, Hou J. Silencing PFKP inhibits starvation-induced autophagy, glycolysis, and epithelial mesenchymal transition in oral squamous cell carcinoma. Exp Cell Res. 2018;370(1):46-57. Epub 2018/06/13. https://doi.org/10.1016/j.yexcr.201 8.06.007.

8. Lee M, Yoon JH. Metabolic interplay between glycolysis and mitochondrial oxidation: the reverse Warburg effect and its therapeutic implication. World J Biol Chem. 2015;6(3):148-61. Epub 2015/09/01. https://doi.org/10.4331/ wjbc.v6.i3.148.

9. Pennington Z, Goodwin ML, Westbroek EM, Cottrill E, Ahmed AK, Sciubba DM. Lactate and cancer: spinal metastases and potential therapeutic targets (part 2). Ann Transl Med. 2019;7(10):221. Epub 2019/07/13. https://doi.org/1 $0.21037 /$ atm.2019.01.85.

10. Cui J, Shi M, Xie D, Wei D, Jia Z, Zheng S, et al. FOXM1 promotes the Warburg effect and pancreatic cancer progression via transactivation of LDHA expression. Clin Cancer Res. 2014;20(10):2595-606 Epub 2014/03/19.

11. Cai H, Li J, Zhang Y, Liao Y, Zhu Y, Wang C, Hou J. LDHA promotes oral squamous cell carcinoma progression through facilitating glycolysis and epithelial-mesenchymal transition. Front Oncol. 2019;9:1446. Epub 2020/01/ 11. https://doi.org/10.3389/fonc.2019.01446.

12. Xu XD, Shao SX, Jiang HP, Cao YW, Wang YH, Yang XC, Wang YL, Wang XS, Niu HT. Warburg effect or reverse Warburg effect? A review of cancer metabolism. Oncol Res Treat. 2015;38(3):117-22. Epub 2015/03/21. https:// doi.org/10.1159/000375435.

13. Kikuchi M, Doi E, Tsujimoto I, Horibe T, Tsujimoto Y. Functional analysis of human P5, a protein disulfide isomerase homologue. J Biochem. 2002; 132(3):451-5. Epub 2002/09/03. https://doi.org/10.1093/oxfordjournals. jbchem.a003242.

14. Wang L, Wang X, Wang CC. Protein disulfide-isomerase, a folding catalyst and a redox-regulated chaperone. Free Radic Biol Med. 2015;83:305-13. Epub 2015/02/24. https://doi.org/10.1016/j.freeradbiomed.2015.02.007.

15. Bai Y, Liu X, Qi X, Peng F, Li H, Fu H, et al. PDIA6 modulates apoptosis and autophagy of non-small cell lung cancer cells via the MAP4K1/JNK signaling pathway. EBioMed. 2019;42:311-25. Epub 2019/03/30. https://doi.org/10.101 6/j.ebiom.2019.03.045.

16. Cheng HP, Liu Q, Li Y, Li XD, Zhu CY. The inhibitory effect of PDIA6 downregulation on bladder cancer cell proliferation and invasion. Oncol Res. 2017;25(4):587-93. Epub 2016/10/21. https://doi.org/10.3727/09650401 6X14761811155298.

17. Negroni L, Taouji S, Arma D, Pallares-Lupon N, Leong K, Beausang LA, Latterich M, Bossé R, Balabaud C, Schmitter JM, Bioulac-Sage P, ZucmanRossi J, Rosenbaum J, Chevet E. Integrative quantitative proteomics unveils proteostasis imbalance in human hepatocellular carcinoma developed on nonfibrotic livers. Mol Cell Proteomics. 2014;13(12):3473-83. Epub 2014/09/ 17. https://doi.org/10.1074/mcp.M114.043174.

18. Xu S, Sankar S, Neamati N. Protein disulfide isomerase: a promising target for cancer therapy. Drug Discov Today. 2014;19(3):222-40. Epub 2013/11/05. https://doi.org/10.1016/j.drudis.2013.10.017.

19. Ramos FS, Serino LT, Carvalho CM, Lima RS, Urban CA, Cavalli IJ, et al. PDIA3 and PDIA6 gene expression as an aggressiveness marker in primary ductal breast cancer. Genet Mol Res. 2015;14(2):6960-7 Epub 2015/07/01.

20. He Y, Shao F, Pi W, Shi C, Chen Y, Gong D, Wang B, Cao Z, Tang K. Largescale transcriptomics analysis suggests over-expression of $\mathrm{BGH}$, MMP9 and PDIA3 in oral squamous cell carcinoma. Plos one. 2016;11(1): e0146530. Epub 2016/01/09. https://doi.org/10.1371/journal.pone.0146530.

21. Samanta S, Tamura S, Dubeau L, Mhawech-Fauceglia P, Miyagi Y, Kato H, Lieberman R, Buckanovich RJ, Lin YG, Neamati N. Expression of protein disulfide isomerase family members correlates with tumor progression and patient survival in ovarian cancer. Oncotarget. 2017;8(61):103543-56. Epub 2017/12/22. https://doi.org/10.18632/oncotarget.21569.

22. Tufo G, Jones AW, Wang Z, Hamelin J, Tajeddine N, Esposti DD, et al. The protein disulfide isomerases PDIA4 and PDIA6 mediate resistance to 
cisplatin-induced cell death in lung adenocarcinoma. Cell Death Differ. 2014;21(5):685-95. Epub 2014/01/28. https://doi.org/10.1038/cdd.2013.193.

23. Gao H, Sun B, Fu H, Chi X, Wang F, Qi X, Hu J, Shao S. PDIA6 promotes the proliferation of HeLa cells through activating the Wnt/beta-catenin signaling pathway. Oncotarget. 2016;7(33):53289-98. Epub 2016/07/28. https://doi.org/10.18632/oncotarget.10795.

24. Herr I, Sahr H, Zhao Z, Yin L, Omlor G, Lehner B, et al. MiR-127 and miR-376a act as tumor suppressors by in vivo targeting of COA1 and PDIA6 in giant cell tumor of bone. Cancer Lett. 2017;409:49-55. Epub 2017/09/04. https:// doi.org/10.1016/j.canlet.2017.08.029

25. Kim TW, Ryu HH, Li SY, Li CH, Lim SH, Jang WY, Jung S. PDIA6 regulation of ADAM17 shedding activity and EGFR-mediated migration and invasion of glioblastoma cells. J Neurosurg. 2017;126(6):1829-38. Epub 2016/08/20. https://doi.org/10.3171/2016.5.JNS152831.

26. Warburg O. On respiratory impairment in cancer cells. Science. 1956; 124(3215):269-70 Epub 1956/08/10.

27. Weinhouse S. On respiratory impairment in cancer cells. Science. 1956;124(3215): 267-9. Epub 1956/08/10. https://doi.org/10.1126/science.124.3215.267.

28. Lunt SY, Vander Heiden MG. Aerobic glycolysis: meeting the metabolic requirements of cell proliferation. Ann Rev Cell Dev Biol. 2011;27(1):441-64. Epub 2011/10/12. https://doi.org/10.1146/annurev-cellbio-092910-154237.

29. Dibble EH, Alvarez AC, Truong MT, Mercier G, Cook EF, Subramaniam RM 18F-FDG metabolic tumor volume and total glycolytic activity of oral cavity and oropharyngeal squamous cell cancer: adding value to clinical staging. J Nuclear Med. 2012;53(5):709-15 Epub 2012/04/12.

30. Clatot F, Gouerant S, Mareschal S, Cornic M, Berghian A, Choussy O, et al. The gene expression profile of inflammatory, hypoxic and metabolic genes predicts the metastatic spread of human head and neck squamous cell carcinoma. Oral Oncol. 2014;50(3):200-7. Epub 2014/01/07. https://doi.org/1 0.1016/j.oraloncology.2013.12.009.

31. Wei J, Wu J, Xu W, Nie H, Zhou R, Wang R, Liu Y, Tang G, Wu J. Salvianolic acid B inhibits glycolysis in oral squamous cell carcinoma via targeting PI3K AKT/HIF-1alpha signaling pathway. Cell Death Dis. 2018;9(6):599. Epub 2018/ 05/24. https://doi.org/10.1038/s41419-018-0623-9.

\section{Publisher's Note}

Springer Nature remains neutral with regard to jurisdictional claims in published maps and institutional affiliations.

Ready to submit your research? Choose BMC and benefit from:

- fast, convenient online submission

- thorough peer review by experienced researchers in your field

- rapid publication on acceptance

- support for research data, including large and complex data types

- gold Open Access which fosters wider collaboration and increased citations

- maximum visibility for your research: over $100 \mathrm{M}$ website views per year

At $\mathrm{BMC}$, research is always in progress.

Learn more biomedcentral.com/submissions 